\title{
DOES GENDER PLAY A ROLE IN TEXT MESSAGING?
}

\author{
Wendy Ceccucci, Quinnipiac University, wendy.ceccucci@quinnipiac.edu \\ Alan Peslak, Penn State University, arp14@psu.edu \\ S. E., Kruck, James Madison University, kruckse@jmu.edu \\ Patricia, Sendall, Merrimack College, sendallp@merrimack.edu
}

\begin{abstract}
This purpose of this research was to study the effect of gender on text messaging (SMS). A comprehensive survey was developed to explore various aspects of text messaging usage. The survey included factors from the Theory of Reasoned Action, Technology Acceptance Model, Theory of Planned Behavior, End User Computer Satisfaction, Expectation/Confirmation Theory, and Diffusion of Innovation. Overall, there was very little statistical difference based on gender with the exception of emotions. All of the positive emotions were higher for females than males. In other words, females were more pleased, satisfied, contented, and delighted with their text messaging experience.
\end{abstract}

Keywords: Text Messaging (SMS), Gender and computer-mediated communication (CMC)

\section{INTRODUCTION}

Short message service (SMS) or what is more commonly referred to as text messaging, or simply texting, allows users to send short messages quickly and privately to a specific individual or group of individuals. Text messaging is a form of computer-mediated communication (CMC) where messages are sent via mobile phone. SMS has established itself as the simplest and easiest means of personalized communication. According to Portio Research[27], 7.8 trillion SMS messages were sent in 2011 and is expected to reach 9.6 trillion in 2012.

In an attempt to understand the effect of gender differences on text messaging, factors from five models on human behavior: Diffusion of Innovation (DI), End User Computer Satisfaction (EUCS), Theory of Reasoned Action (TRA), Theory of Planned Behavior (TPB), and Technology Acceptance Model (TAM) were explored. Emotional factors were also investigated.

This research looked at text messaging behavior using variables from the Rogers [30] model of human behavior known as Diffusion of Innovation (DI). According to Rogers, important characteristics of an innovation include:

- Relative Advantage - the degree to which it is perceived to be better than what it supersedes

- Compatibility - consistency with existing values, past experiences and needs

- Complexity --difficulty of understanding and use

- Visibility -- the visibility of its results

Ajzen and Fishbein [3] developed the Theory of Reasoned Action (TRA) model. TRA suggests that a person's behavioral intention depends on the person's attitude about the behavior and subjective norms. If a person intends to do a behavior then it is likely that the person will do it. This research looks at the differences in attitude based upon gender. The Theory of Planned Behavior (TPB) is an extension of the TRA model and was developed by Ajzen [3]. Ajzen added a new factor, perceived behavioral control to the original TRA Model.

The Technology Acceptance Model (TAM) includes two key factors, perceived usefulness and perceived ease of use that are proposed to influence acceptance of a technology. According to Davis [8] perceived usefulness is defined as "the degree to which a person believes that using a particular system would enhance his or her job performance". Perceived ease of use is "the degree to which a person believes that using a particular system would be free of effort" [8]. 


\section{Issues in Information Systems}

Volume 14, Issue 2, pp.186-194, 2013

The End User Computing Satisfaction Instrument (EUCS) developed by Doll and Torkzadeh [9], defined five factors that influence user satisfaction: content, accuracy, format, ease of use, and timeliness. User satisfaction is defined as the "extent to which users perceive that the information system available to them meets their information requirements" [37]. User computer satisfaction is often used as a measure of user perception of the effectiveness of an MIS [5, 10].

The effect of emotions on performance has been noted by many researchers [24, 31, 35]. The impact of these emotions has been included in our study.

\section{Text Messaging}

\section{LITERATURE REVIEW}

Text messaging turned 20 last December. The first text message, "Merry Christmas," was sent on December 3, 1992. Then a little over a year later the first commercial text messaging service was launched by Radiolinja, a Finnish company. Finally in 2008, more text messages were sent than phone calls made. The growth can be seen in the following figure [14].

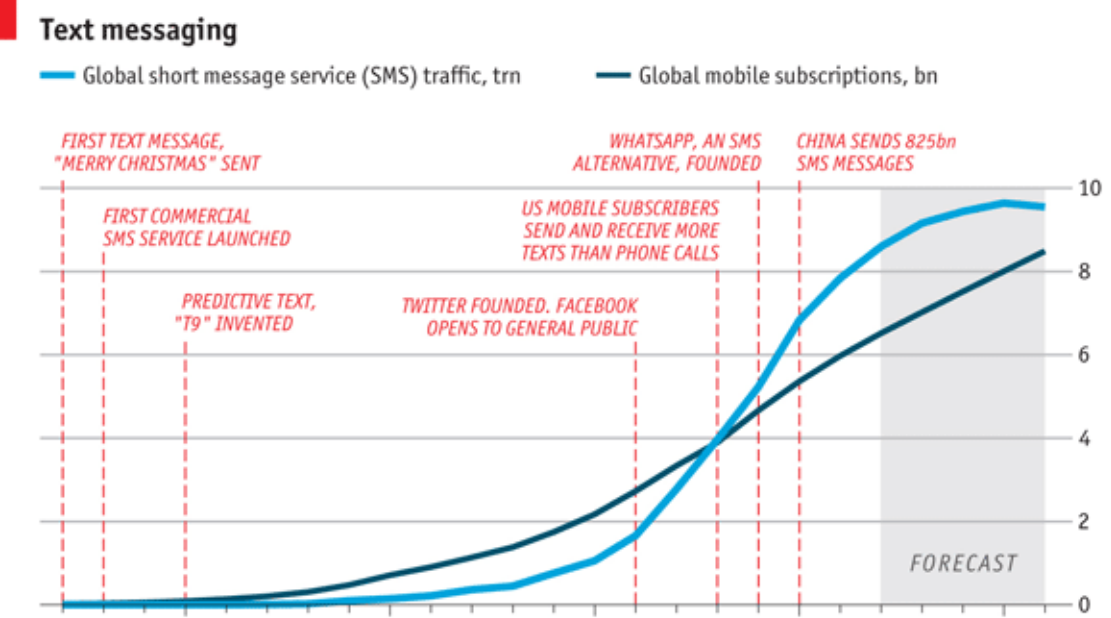

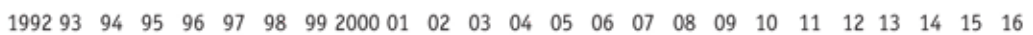
Sources: Portio Research; Nielsen; Acision; national sources

Economist.com/graphicdetail

According to the Pew Internet \& American Life Project Report[33] text messaging users "send or receive an average of 41.5 messages on a typical day, with the median user sending or receiving 10 texts daily" The 18-24 age group is the largest user of text messaging sending or receiving an average of 109.5 messages daily[33]. Below are some interesting statistics taken from NetBlueWeb [23] on the use and response time of text messaging.

- Voice calling is decreasing as text messaging increases amongst American adults

- Over 8 trillion text messages were sent in 2011 which makes this service surpass traditional telephone conversations

- $90 \%$ of all text messages are read within 3 minutes of their delivery

- $97 \%$ of text messages are opened, while only $22 \%$ of emails are opened

- The average response time it takes to respond a text message is 90 seconds

- $45 \%$ of $21-50$ year olds polled prefer texting to voice calling

- $50 \%$ of all text message users in the United States are over the age of 35 .

\section{Gender}




\section{Issues in Information Systems \\ Volume 14, Issue 2, pp.186-194, 2013}

A number of research studies have found that females spend more time texting and send more messages in a day than do males [6, 12, 20,29]. Igarashi, Jiro, and Toshikazu [15] studied Japanese university freshman and looked at the gender differences in communication via text messaging. They determined that the volume of text messaging did not vary by gender. However the social relationship network maintained by text messaging was different. At later stages of text messaging females tended to form a large group comparable to face to face communication. Pruthikrai [28] found that gender had no significant effect on text-messaging activity.

Ilie, Van Slyke, Green, \& Lou [17] used diffusion theory to examine gender difference in perceptions and use of instant messaging. The authors determined that women value perceptions of ease of use and visibility more than men, while men value perceptions of relative advantage, the perceived utility and the perceived popularity or critical mass more than women. Women focused more on the social aspects, while men focused more on task completion. Peslak, Ceccucci and Sendall [24] studied instant messaging usage and their results supported only one of Ilie's findings, that there are gender differences in how relative advantage influences their intentions to use instant messaging.

Balakrishnan and Yeow [6] looked at the physical aspects of texting, specifically the speed and efficiency of text entry. They found that females were more satisfied than males. They theorized two possible reasons for this. First, females have smaller fingers making key pressing easier and faster. The second reason is that females text more often which makes them an expert in keying in the text. Vankatesh and Morris [38] found that males and females differ in the adoption and use of technology in that women tend to be more open to the technology if it has a certain level of ease of use. Another reason cited is that females tend to be more persuaded by peer-influenced normative pressures to adopt the technology than are men.

Balakrishnan \& Yeow [6] also looked at how easy it was to learn how to text. They found that males were more satisfied than females with respect to learnability. They stated that,

“...males have the capability of learning and understanding technical things faster than the females, thus making them to be more satisfied than females. All six females in their twenties and thirties agreed that learning the art of texting was difficult as it seems to be a complex feature. Learning the method to make key presses and knowing the mapping of other characters to the keys were cited as the major obstacles. Females also have the tendency to include more literary flourishes like proper salutations, capitalization and punctuations in their messages. They are also more likely to write longer and complex messages that include emotional elements in their communications." [6, pg.92]

Grellhesl and Punyanunt-Carter from Indiana University[15], applied the uses and gratifications theory (UGT) to understand why students use text messaging and the purpose of using text messaging. UGT looks at how users deliberately choose media that will satisfy given needs and allow a person to enhance knowledge, relaxation, social interactions/companionship, diversion, or escape. Grellhesl and Punyanunt-Carter [15] looked at the gratifications sought through text messaging practices of male and female undergraduate students. They found three areas in which males and females differed. They found that while both males and female students ranked "access and mobility" as the highest gratification factor, females reported significantly higher scores for "access and mobility" than did males. The authors stated one possibility for this might be due that females generally make more contact with family members, and engage in detailed conversations while on the go as opposed to males who used their mobile phone primarily for business purposes or brief conversations.

The second area, in which they found significant differences, was in the area of relaxation or escape. The results of their study showed that college-age females reported higher scores in relaxation or escape than males. The researchers asserted that one possibility for this finding was that past studies [21,31] have suggested even though males tend to have more friends, females tend to share more details with other females, and be more spontaneous. Zeng, Burrow-Sanchez and Drew [38] also found that CMC with friends can be a form of relaxation and escape.

Just as face-to-face communications are different between men and women, so are computer-mediated communication. Studies suggest that women are often more expressive and social than men. Women will have 


\section{Issues in Information Systems \\ Volume 14, Issue 2, pp.186-194, 2013}

more conversation-type text messaging, and more in-depth conversations with good friends. Women also tend to communicate with more text messages for the similar communications because with CMC, the nonverbal cues are missing. When men text, they have a purpose or task in mind to complete and they often use text messaging to gain social status.

Acision, a large global mobile messaging company headquartered in the UK, recently released a report entitled 'Psychology of SMS' [4]. The research contained responses from 1,000 adults in the UK and 1,000 adults in the US. The report examined the behaviors behind text message usage. Their survey found that males text more contacts than females, on average messaging 17 people regularly, while females tend to text the same 13 people. Males tend to use texting as a functional, easy way to communicate without getting into a conversation - a way of avoiding lengthy phone calls. Females tend to see it more as an additional communication medium, and are more likely to send longer text messages (41\%) or SMSs that say 'I love you' (54\%) [4]. Acision believes this is to 'deepen relationships'. Males in the workplace are three times more likely to text a work colleague than females, but as many as $15 \%$ of mobile users in the UK have called in sick via text message - again using text to avoid a conversation.

Herring and Zelenkauskaite [18] looked at how text messaging is changing the way in which females and males have traditionally communicated. They analyzed 1,164 gender-defined messages posted on an Italian reality interactive music television channel. They found that females write longer messages, using more emoticons and abbreviations. Although females were both more economical and expressive, they came closer to maxing out, or did max out, on the 160-character message limit more often than their male counterparts [18].

More recently, Kimbrough, Guadagnob, Muscanelle \& Dilld [19] found that females, compared to males, are generally more frequent mediated communication users. Compared to men, women both prefer and more frequently use text messaging, social media, and online video calls.

\section{RESEARCH METHODOLOGY}

The statistical analyses were based on a sample of 153 completed surveys. Since the surveys were collected in undergraduate college classes, the response rate was near 100\%. Of the surveys collected $63(42 \%)$ were from males and $89(58 \%)$ were from females. Overall, the average age was about 33 years of age, but 55\% of the sample population was the 18-24 year old students. Their remaining portion of the sample (45\%) was over 24 .

Another demographic question examined the current professional status of the respondent, whether they were a student, a faculty member, an IT professional or from the other professions. Eighty-six (57\%) of the respondents were students, $11(7 \%)$ were faculty members, 11 (7\%) IT professionals, and $43(29 \%)$ were from other professions. We propose the sample has a reasonable mix of gender, age, and professional status.

\section{RESEARCH APPROACH}

A comprehensive survey was developed to explore all aspects of text messaging usage. The survey included key questions used in the development of past studies of Theory of Reasoned Action, Technology Acceptance Model, Theory of Planned Behavior, End User Computer Satisfaction, Expectation/Confirmation Theory, and Diffusion of Innovation. Table 1 shows the variables, model, and source for questions that were used in this study. One key question was selected for each variable. The study was pre-tested with a small group of students and then administered to students and faculty at two Northeastern universities as well as a limited group of professionals in industry.

Table 1: Variable Models and References

\begin{tabular}{|l|l|l|l|}
\hline Variable & Actual survey question & Model & Questions adapted from \\
\hline Attitude & Text messaging is good. & TRA/TPB & Fitzmaurice [13] \\
\hline Compatibility & $\begin{array}{l}\text { Text messaging is completely } \\
\text { compatible with my current } \\
\text { situation. }\end{array}$ & DI & Ilie, Van Slyke, Green, \& Lou [17] \\
\hline
\end{tabular}




\section{Issues in Information Systems}

Volume 14, Issue 2, pp.186-194, 2013

\begin{tabular}{|l|l|l|l|}
\hline Complexity & Text messaging is frustrating & DI & Ilie, Van Slyke, Green, \& Lou [17] \\
\hline Critical Mass & $\begin{array}{l}\text { Many people use Text } \\
\text { messaging. }\end{array}$ & DI & Ilie, Van Slyke, Green, \& Lou [17] \\
\hline Ease of Use & Text messaging is easy to do. & TAM /EUCS & Davis [8] \\
\hline Emotions & $\begin{array}{l}\text { Pleased Satisfied Contented } \\
\text { Delighted }\end{array}$ & Emotions & Peslak and Stanton [25] \\
\hline $\begin{array}{l}\text { Perceived } \\
\text { Behavioral } \\
\text { Control }\end{array}$ & $\begin{array}{l}\text { Text messaging is entirely within } \\
\text { my control. }\end{array}$ & TPB & Venkatesh \& Morris [37] \\
\hline $\begin{array}{l}\text { Relative } \\
\text { advantage }\end{array}$ & $\begin{array}{l}\text { Text messaging improves my } \\
\text { productivity. }\end{array}$ & DI & George [14] \\
\hline Timeliness & $\begin{array}{l}\text { Text messaging provides needed } \\
\text { information quickly }\end{array}$ & EUCS & Fitzmaurice [13] \\
\hline Usefulness & I find Text messaging useful & TAM & $\begin{array}{l}\text { Abdinnour-Helm, Chaparro, \& } \\
\text { Farmer [1] }\end{array}$ \\
\hline Visibility & $\begin{array}{l}\text { I have seen many people Text } \\
\text { messaging. }\end{array}$ & DI & Davis [8] \\
\hline
\end{tabular}

\section{RESULTS}

The variables noted above were analyzed using SPSS 20.0 using independent samples t-tests of means. Gender $(1=$ Female, $2=$ Male $)$ was used as the grouping variable and means were compared for significant difference for each of the fourteen variables. Tables 2 and 3 show the descriptive statistics results of this analysis. The Likert-type scale ranged from $1=$ Strongly Disagree through $7=$ Strongly Agree, with the exception of the emotions which were reversed scored.

Table 2 Overall Descriptive Statistics

\begin{tabular}{|l|r|r|r|r|}
\hline & N & Mean & Std. Deviation & Scaled Desc. \\
\hline Text messaging is good. & 124 & 5.05 & 1.908 & Somewhat Agree \\
\hline Text messaging is compatible with how I communicate. & 122 & 4.41 & 1.808 & Neutral \\
\hline Text messaging is frustrating. & 123 & 3.33 & 1.682 & Somewhat Disagree \\
\hline Many people use Text messaging. & 125 & 5.51 & 2.085 & Agree \\
\hline Text messaging is easy to do. & 124 & 5.01 & 1.737 & Somewhat agree \\
\hline Pleased & 121 & 2.91 & 1.432 & Somewhat agree \\
\hline Satisfied & 121 & 2.81 & 1.416 & Somewhat agree \\
\hline Contented & 122 & 2.94 & 1.410 & Somewhat agree \\
\hline Delighted & 119 & 3.08 & 1.488 & Somewhat agree \\
\hline Text messaging is entirely within my control. & 124 & 5.17 & 1.756 & Somewhat Agree \\
\hline Text messaging improves my productivity. & 123 & 4.33 & 1.652 & Neutral \\
\hline Text messaging provides needed information quickly. & 121 & 5.23 & 1.797 & Somewhat Agree \\
\hline I find Text messaging useful. & 120 & 5.12 & 1.911 & Somewhat Agree \\
\hline I have seen many people Text messaging. & 121 & 5.77 & 1.909 & Agree \\
\hline
\end{tabular}

Table 2 shows the overall results of the survey. Respondents generally agree about the widespread usage of text messaging. They generally somewhat agree with several common positive emotions (pleased, satisfied, contented, and delighted) in regards to text messaging. They are less favorable about other aspects of text messaging. They are 


\section{Issues in Information Systems \\ Volume 14, Issue 2, pp.186-194, 2013}

neutral on its productivity aspects and compatibility with their communications preferences. They do have small (somewhat) agreement that text messaging is good, easy, within their control, useful, and speedy. The level of agreement though is generally low suggesting a less than ideal communications vehicle. Respondents also disagree that it is somewhat frustrating.

Table 3 Descriptive Statistics by Gender

\begin{tabular}{|c|c|c|c|c|c|}
\hline & Gender & $\mathrm{N}$ & Mean & Std. Dev & $\begin{array}{c}\text { Std. Error } \\
\text { Mean }\end{array}$ \\
\hline \multirow{2}{*}{ Text messaging is good. } & female & 73 & 5.11 & 1.969 & .230 \\
\hline & male & 51 & 4.96 & 1.833 & .257 \\
\hline \multirow{2}{*}{$\begin{array}{l}\text { Text messaging is completely compatible with my current } \\
\text { situation. }\end{array}$} & female & 72 & 4.39 & 1.812 & .214 \\
\hline & male & 50 & 4.36 & 1.687 & .239 \\
\hline \multirow{2}{*}{ Text messaging is frustrating. } & female & 73 & 3.37 & 1.791 & .210 \\
\hline & male & 50 & 3.28 & 1.526 & .216 \\
\hline \multirow{2}{*}{ Many people use Text messaging. } & female & 73 & 5.51 & 2.161 & .253 \\
\hline & male & 52 & 5.52 & 1.995 & .277 \\
\hline \multirow{2}{*}{ Text messaging is easy to do. } & female & 73 & 5.03 & 1.871 & .219 \\
\hline & male & 51 & 4.98 & 1.543 & .216 \\
\hline \multirow{2}{*}{ Pleased } & female & 70 & 2.60 & 1.290 & .154 \\
\hline & male & 51 & 3.33 & 1.519 & .213 \\
\hline \multirow{2}{*}{ Satisfied } & female & 70 & 2.53 & 1.248 & .149 \\
\hline & male & 51 & 3.20 & 1.549 & .217 \\
\hline \multirow{2}{*}{ Contented } & female & 70 & 2.63 & 1.253 & .150 \\
\hline & male & 52 & 3.37 & 1.509 & .209 \\
\hline \multirow{2}{*}{ Delighted } & female & 68 & 2.69 & 1.341 & .163 \\
\hline & male & 51 & 3.61 & 1.524 & .213 \\
\hline \multirow{2}{*}{ Text messaging is entirely within my control. } & female & 72 & 5.14 & 1.886 & .222 \\
\hline & male & 52 & 5.21 & 1.576 & .219 \\
\hline \multirow{2}{*}{ Text messaging improves my productivity. } & female & 72 & 4.29 & 1.748 & .206 \\
\hline & male & 51 & 4.37 & 1.523 & .213 \\
\hline \multirow{2}{*}{ Text messaging provides needed information quickly. } & female & 69 & 5.32 & 1.867 & .225 \\
\hline & male & 52 & 5.12 & 1.711 & .237 \\
\hline \multirow{2}{*}{ I find Text messaging useful. } & female & 69 & 5.23 & 2.016 & .243 \\
\hline & male & 51 & 4.96 & 1.766 & .247 \\
\hline \multirow{2}{*}{ I have seen many people Text messaging. } & female & 69 & 5.77 & 2.080 & .250 \\
\hline & male & 52 & 5.77 & 1.676 & .232 \\
\hline
\end{tabular}

Table 3 presents these descriptive statistics based on gender. In general, many of the variables show remarkable similarity based on gender. Only a few variables seem to show sizable differences based on gender.

Table 3 ANOVA of Variances by Gender* 


\section{Issues in Information Systems}

Volume 14, Issue 2, pp.186-194, 2013

\begin{tabular}{|c|c|c|c|c|}
\hline & $\mathrm{F}$ & $\mathrm{t}$ & df & $\begin{array}{l}\text { Sig. (2- } \\
\text { tailed) }\end{array}$ \\
\hline Text messaging is good. & 0.678 & 0.426 & 122 & 0.671 \\
\hline Text messaging is completely compatible with my current situation. & 0.825 & 0.089 & 120 & 0.929 \\
\hline Text messaging is frustrating. & 3.963 & 0.29 & 121 & 0.772 \\
\hline Many people use Text messaging. & 0.332 & -0.033 & 123 & 0.974 \\
\hline Text messaging is easy to do. & 1.949 & 0.148 & 122 & 0.883 \\
\hline Pleased & 0.321 & -2.864 & 119 & 0.005 \\
\hline Satisfied & 1.359 & -2.622 & 119 & 0.01 \\
\hline Contented & 1.068 & -2.943 & 120 & 0.004 \\
\hline Delighted & 0.001 & -3.479 & 117 & 0.001 \\
\hline Text messaging is entirely within my control. & 2.356 & -0.226 & 122 & 0.821 \\
\hline Text messaging improves my productivity. & 4.146 & -0.266 & 121 & 0.79 \\
\hline Text messaging provides needed information quickly. & 0.026 & 0.615 & 119 & 0.54 \\
\hline I find Text messaging useful. & 1.094 & 0.767 & 118 & 0.445 \\
\hline I have seen many people Text messaging. & 1.882 & -0.003 & 119 & 0.997 \\
\hline
\end{tabular}

*Equal Variances assumed

In order to determine the statistical significance of these gender variations an independent samples t-test was performed. Table 3 shows the results of that analysis. Overall, all of the statements show no statistical difference based on gender with the exception of the emotions. All of the positive emotions listed were higher for females than males. In other words, females were more pleased, satisfied, contented, and delighted with their text messaging experience. This is consistent with findings of several other researchers. Balakrishnan and Yeow [6] found that females were more satisfied than men in regards to the speed and efficiency of text entry. Grellhesl and PunyanuntCarter [15] applied the Users Gratification Theory and found that females reported significantly higher gratification or motive scores for "access and mobility" and" relaxation or escape" than did males.

The difference in emotions may relate to some fundamental communication preference differences between males and females. None of the other variables, attitude, complexity, compatiblity, critical mass, ease of use, emotions, relative advantage, timeliness and usefulness showed any differences based upon gender. Although Balakrishnan and Yeow [6] did find difference in learnability, our research indicates that they were no differences based on the complexity and use of use. This may be due to the fact that once females have used the technology they no longer consider it difficult to use or complex.

\section{CONCLUSIONS}

Overall, this study has an analysis of variables that influence and affect text messaging. We see this as the continuation of an exploration of ways to increase and improve penetration of this valuable communications technology. Studies can be developed to confirm these findings with larger and more diverse sample groups, but preliminary findings suggest that objective variables are no longer affected by gender with regard to text messaging. There does seem to be some emotional difference between genders on text messaging usage. Further study is 


\section{Issues in Information Systems}

Volume 14, Issue 2, pp.186-194, 2013

warranted to explore the causes of this emotional difference to advance the penetration of this importance communications tool.

\section{REFERENCES}

1. Abdinnour-Helm, S. F., Chaparro, B. S., and Farmer, S. M. (2005). Using the End-User Computing Satisfaction (EUCS) instrument to measure satisfaction with a web site. Decision Sciences, 36(2), 341-365.

2. Abratt, R., Nel D., \& Higgs, S. N. (1992). An examination of the ethical beliefs of managers using selected scenarios in a cross-cultural environment. Journal of Business Ethics, 11(1), 29-35.

3. Ajzen, I. \& Fishbein, M. (1980). Understanding Attitudes and Predicting Social Behavior. Englewood Cliffs: Prentice-Hall, Inc.

4. Acision (2012). The psychology of SMS: Why do we still love to text. retrieved from: http://www.acision.com/News-and-Events/Press-Releases/All-Destinations/2012/The-psychology-of-SMSWhy-we-still-love-to-text.aspx

5. Bailey, J., \& Pearson, S. (1983). Development of a Tool for Measuring and Analyzing Computer User Satisfaction, Management Science, 29(5), 530-545.

6. Balakrishnan, V. \& Yeow, P. (2007). Texting satisfaction: does age and gender make a difference? International Journal of Computer Science and Security, 1(1), 85-96.

7. Benham, H. C., \& Wagner, J. L. (1995). Ethical attitudes of business students and MIS personnel. Proceedings of the ACM SIGCPR Conference [online], Nashville TN USA, 44-49. Available: www.acm.org/pubs/articles/proceedings/cpr/212490/p44-wagner/p44-wagner.pdf

8. Davis, F. D. (1989). Percieved Usefulness, Perceived Ease of Use, and User Acceptance of Information Technology. MIS Quarterly, 13(3), 319-340.

9. Doll, W., \& Torkzadeh, G. (1988). The measurement of end-user computing satisfaction," MIS Quarterly, 12(6), 259-274.

10. Doll, W., Xia, W., \& Torkzadeh, G. (1994). A confirmatory factor analysis of the end-user computing satisfaction instrument, MIS Quarterly, 18(4), 453-461.

11. Fallows, D. (2005, December). How women and men use the Internet. http://www.pewinternet.org/Reports/2005/How-Women-and-Men-Use-the-Internet.aspx

12. Faulkner, X. \& Culwin, F. (2005). When Fingers Do The Talking: A Study of Text Messaging. Interacting with Computers, 17, 167-185.

13. Fitzmaurice, J. (2005) Incorporating Consumers' Motivations into the Theory of Reasoned Action. Psychology \& Marketing, 22(11), 911-929.

14. George, J. (2004). The theory of planned behavior and Internet purchasing. Internet Research, 14(3), 198-212.

15. Grellhesl, M. \& Punyanunt-Carter, N. (2012). Using the uses and gratifications theory to understand gratifications sought through text messaging practices of male and female undergraduate students. Computers in Human Behavior, 28, 2175-2181.

16. Igarashi, T., Jiro, T., \& Toshikazu, Y. (2005). Gender differences in social network development via mobile phone messages: a longitudinal study. Journal of Social and Personal Relationships, 22( 5), 591-713.

17. Ilie, V., Van Slyke, C., Green, G., and Lou, H. (2005). Gender Difference in Perception and Use of Communication Technologies: A Diffusion of Innovation Approach. Information Resources Management Journal. 18(3), 13-31.

18. Indiana University (2009, February 26). When Texting, Eligible Women Express Themselves Better. ScienceDaily, retrieved April 8, 2013.

19. Kimbrough, Amanda M. , Guadagnob, Rosanna E., Muscanelle, Nicole \& Dilld, Janeann (2013), Gender differences in mediated communication: Women connect more than do men, Computers in Human Behavior, 29, 3 896-900.

20. Ling, R. (2003). The Socio-linguistic of SMS: An Analysis of SMS Use by a Random Sample of Norwegians. Mobile Communications: Renegotiation of the Social Sphere, Ling, R. and Pedersen, P. (Eds.), pp. $335-349$ (London: Springer, 2003).

21. Macoby, E. E., \& Jacklin, C. N. (1974). The psychology of sex differences in self disclosure. Sex Roles, 2, 161166.

22. Muscanell, N.L. \& Guadagno, R.E., (2012). Make new friends or keep the old: Gender and personality differences in social networking use. Computers in Human Behavior, 28, 107-112.

23. NetBlueWeb, (2012) Text Messaging Marketing. Retrieved from http://netblueweb.com/services/text-message- 


\section{Issues in Information Systems}

Volume 14, Issue 2, pp.186-194, 2013

marketing.

24. Peslak, A., Ceccucci, W., \& Sendall, P. (2010)An Empirical Study of Instant Messaging Behavior Using Diffusion of Innovation Theory, Journal of Information Systems Applied Research, 3(18), 3-13.

25. Peslak, A. R. (2005). Emotions and team projects and processes. Team Performance Management , 11(7/8), 251-262.

26. Peslak, A. \& Stanton, M. (2007) Information technology team achievement: an analysis of success factors analysis and development of a team success model (TSM). Team Performance Management, 13(1/2), 21-33.

27. Portio Research, (2012). Mobile Messaging Futures 2012- 2016, retrieved from MobiThinking, http://mobithinking.com/mobile-marketing-tools/latest-mobile-stats/c\#mobilemessaging

28. Pruthikrai, M. (2007). The Effects of Personality Traits and Optimum Stimulation Level on Text-Messaging Activities and M-commerce Intention. International Journal of Electronic Commerce, 12(1), 7-30.

29. Reid, F.J.M. \& Reid, D.J., (2004). Text Appeal: The Psychology of SMS Texting and Its Implications for the Design of Mobile Phone Interfaces. Campus Wide Information Systems, 21, 196-200.

30. Rogers, E. (1995) Diffusion of Innovations, 4th Edition. New York, NY: Free Press.

31. Seiden, A. M., \& Bart, P. B., (1975). Woman to woman: Is sisterhood possible? N.Glazer-Malbin (Ed.), Old family/new family: Interpersonal relationships. New York: Van Nostrand.

32. Shaw, T. (2004). The emotions of systems developers: an empirical study of affective events theory. Proceedings of SIGMIS'04, 124-6.

33. Smith, Aaron. (2011) Americans and text messaging. Pew Internet \& American Life Project. Retrieved from http://pewinternet.org/Reports/2011/Cell-Phone-Texting-2011/Summary-of-Findings.aspx.

34. Somers, T., Nelson, K., \& Karimi, J. (2003). Confirmatory factor analysis of the end-user computing satisfaction instrument: Replciation with an ERP doomain. Decision Science, 34(3), 595-621.

35. Sy, T., Cote, S., \& Saavedra, R. (2005). The contagious leader: impact of the leader's mood on the mood of group members, group affective tone, and group processes. Journal of Applied Psychology, 90(2), 295-305.

36. The Economist (2012) OMG! Texting turns twenty, 3 Dec 2012 Retrieved from http://www.economist.com/blogs/graphicdetail/2012/12/daily-chart.

37. Tornatzky, L., \& Fleischer, M. (1990). The Processes of Technological Innovation. Lexington, MA: DC Heath and Company.

38. Venkatesh, V., \& Morris, M. (2000). Why Don't Men Ever Stop to Ask for Directions? Gender, Social Influence, and Their Role in Technology Acceptance and Usage Behavior. MIS Quarterly, 24(1), 115-39.

39. Zheng, R., Burrow-Sanchez, J. J., \& Drew, C. (2008). Adolescent online social behavior: Relationship formation on the internet. Hershey, PA: IGI Global Inc. 